DOI: 10.20472/IAC.2018.036.044

\author{
NADHAKAN SHINNARANANTANA \\ Faculty of Business Administration, KASETSART UNIVERSITY, Thailand
}

\title{
INTERNET SHOPPING AND BUYING BEHAVIOR OF BABY BOOMERS IN BANGKOK, THAILAND
}

\begin{abstract}
:
Nowadays retailers have using multichannel of distribution, especially they are more focus on Internet shopping. Because of today consumers are more using internet for several activities such as entertainment, searching for information, social media and also shopping. This conceptual paper focus on internet shopping of Baby Boomers and their buying behavior. Adult consumers are specifically targeted because of their buying power and they are high potential customers for Internet retailer. The study specially address the issues how often and why Internet purchase is made. The $6 \mathrm{Ws}$ and $1 \mathrm{H}$ of buying behavior are asked; who are in the target market, what do they buy, why do they buy, who participate in the buying, when and where do they buy and how do they buy. Regarding the design, methodology, and approach of this paper, a thorough literature investigation will conduct through major databases of leading academic journals and research papers related to the scope of this paper in both Thai and English. An analysis of literature reviews of relevant articles will carry out and present in the paper. The study will provide a vital information for marketers and retailers to develop effective online marketing strategy.
\end{abstract}

\section{Keywords:}

Internet Shopping, Buying Behavior, Baby Boomers, Bangkok Thailand

JEL Classification: M31 